\title{
Important Physical Characteristics for Quality Teacher Education: The Delphi Study ${ }^{1}$
}

\author{
Dürdane LAFCI-TOR ${ }^{2}$ \\ Erciyes University Faculty of Education, Orcid ID: 0000-0003-2373-1247
}

\begin{abstract}
Physical environment in higher education has been of interest since especially the beginning of the 21st century however very a few studies on this topic have been conducted for teacher education in Turkey. In this study, the main purposes were to identify the essential characteristics of physical environment to access quality teacher education and to discuss the importance and role of these physical characteristics for effective and efficient teacher education. A Delphi study with three phases was utilized as a research methodology. In the first phase of the study, data were obtained by one open ended question from 33 teacher candidates in three state and one private universities at Ankara and content analysis was used to analyze data. Then, the questionnaire developed according to the results of the first phase, was applied in two times in a one month interval. Data obtained by the second and the third phases of the study was analyzed by descriptive analysis and then, comparison between two applications was presented in the paper. As a result of the study, technology, ambient environment of the building and classrooms, the cleanliness of environment, the size of the classrooms, furniture and materials, spaces for social and academic activity were emerged as the most important physical characteristics. In discussion part, the importance and role of those places and physical characteristics for teacher education were discussed and presented.

Keywords: Delphi study, teacher education, physical environment

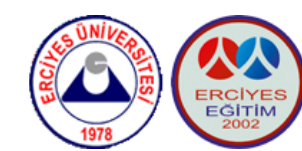

Erciyes University, Faculty of Education,

Kayseri/TURKEY

Erciyes Journal of

Education (EJE)

DOI: $X X X X X X X X$

SCREENED BY

$\checkmark$ iThenticate
\end{abstract}

Suggested Citation

Tor, D. (2017). Important physical characteristics for quality teacher education: The delphi study. Erciyes Journal of Education, 1(2), 23-33. DOI: XXXXXXXXXXXXXX

1. This study is presented at the International Association People Environment Studies (IAPS) Conference, 2012, Glasgow, UK.

2. Dr., Department of Educational Science, Curriculum and Instruction, durdanetor@erciyes.edu.tr, durdaneltor@gmail.com 


\section{INTRODUCTION}

There is always an interest in teacher education. Teachers are the main supporters of an effective and qualified education. They carry a great deal of weight and responsibility of teaching in order to educate the future generation. The paramount question is: "how teacher education should be to fulfill all those responsibilities?" Answering this question is not easy because there are many factors influencing teacher education such as curriculum, quality instructors, quality institution, and so on. The physical environment is another factor, which is underrated until 21st century. Physical environment is one of the important factors which has role on students' emotion, success, motivation and socialization.

Many authors discussed and showed the role of the physical environment in broader manner. The physical environment is considered as the second teacher because it is effective to organize and promote pleasant relationship between people of different ages (Sanoff, Pasalar, \& Hashas, 2001). Learning spaces determine the nature of interaction between students and students, students and instructors and so they determine educational results (Van Note Chism, 2006). According to Edward and Usher (2000), space is relational. That is, it is a product of social relations and at the same time, it produces social relations.

Additionally, physical environment also provides changes, promotes choices and activities, and enhances social, cognitive, and affective learning (Sanoff, Pasalar, \& Hashas, 2001). Moreover, the space within the school shows the ideas, values, and attitudes, and cultures of the people who use it (Sanoff, Pasalar, \& Hashas, 2001). Also as stated by Slattery, the space in which individuals place themselves or are placed affects their inner experiences. Therefore, existence and absence of space for a particular course and activity can influence experiences of teacher candidates. Besides, Zeichner (2008) indicated that "the emphasis of different settings in the education of teachers has reflected different visions of the role of the teacher and of the school in relation to the community which can be in tension with one another" (p. 263). In order for prospective teachers to be effective professionals and for teacher educators to motivate them with the notion of teaching profession, buildings where education takes place would create effect on development professional and/or occupational features of a teacher candidate.

Although the potential influence of the physical environment in higher education has been accepted by many scholars (Gee, 2006; Graetz \& Goliber, 2002; Jameison, 2003; Jessop, Gubby, \& Smith, 2011; Temple 2007, 2009, 2014), information on appropriate physical environment for teacher education is deficient. The education building should be suitable to the field of education. At the same time, the physical environment is defined to include all those aspects of the inanimate world that surround and may influence individuals and communities (Moore, 1987). Because there are many contents about it, it is essential to get information about which physical characteristics are priorities that should be taken into consideration. Hence, this study has attempted to contribute to the knowledge of which physical characteristics of educational settings are important for efficient and effective teacher education.

While faculties are founded and maintained, many professional people (engineers, architects, administrators and so on) are involved in the process; however their contributions are independent from each other or so rare. In this process, the name of any teacher candidate is not there. Because each participant has unique and different ideas and experiences, they should communicate with each other while considering the design of a faculty in order to establish a well-designed faculty building for teacher education. Therefore, teacher candidates as main 
users of the building ought to provide their opinions and experiences which may be useful for construction and for any changes. Thus, the main purposes of this study are to understand teacher candidates' needs in terms of physical environment and to provide these to professionals about which physical characteristics of faculty building are important. Correspondingly, two main research questions were searched: (1) Which physical characteristics of faculty building are essential for quality teacher education? and (2) What are the roles of these characteristics for the continuing growth and development of teacher candidates?

\section{METHOD}

\section{Data Collection Method}

As a research methodology, a Delphi study was utilized in order to reach the answers to the research questions. Delphi is a method which enables structuring a group communication process so that the process is effective in allowing a group of individuals, as a whole, to deal with a problem. Linstone and Turoff defined Delphi process as "structured communication". For successful structured communication, "there is provided: some feedback of individual contributions of information and knowledge; some assessment of the group judgment or' view; some opportunity for individuals to revise views; and some degree of anonymity for the individual responses (2002, p.3).

The Delphi method have considerable advantages that make it useful: (1) Participants have chance to re-evaluate their own and others' answer after analysis of the group response (Clayton, 1997) and (2) They have opportunity to see other participants' perspective and so they can make comparison to clarify and change their views (Skulmoski, Hartman \& Krahn, 2007). Because of these strengths, Delphi was chosen as an appropriate method to enable participants to elaborate the physical environment for teacher education more effectively.

\section{Sampling}

In this study, teacher candidates were selected through qualitative purposeful sampling which depends on the purpose of the study. Purposeful sampling focuses on selecting rich cases and key informants (Miles \& Huberman, 1994; Patton, 2002). Maximum variation sampling method was applied in order to select informants. The reason behind the use of maximum variation sampling method was to gather different experiences and insights from students who use different education building. Therefore, the participants were selected from four different universities in capital city of Turkey, Ankara. Moreover, a group of informants are drawn from different departments such as Elementary Science Education, Elementary Mathematics Education, Elementary Education, Early Childhood Education, Chemistry Education and Physics Education. Consequently, 33 informants in the first, 31 informants in the second and 25 informants in the last phase joined the present study.

\section{Data Collection Process}

This study consisted of the following three phases. In the first phase of the Delphi Study, researcher prepared one open ended question to elaborate the Delphi topic. After taking opinions from four experts working in Faculty of Educational Sciences, the final question was "which physical characteristics of the education building should have for effective and efficient teacher education and why these characteristic are important? This question and demographic 
information sheet was sent to each participant's e-mail address. 33 teacher candidates participated and sent back these to researchers' e-mail until the 4th of November, 2011. Participants provided around 10 physical characteristics. Then, the researcher analyzed the data and prepared survey questionnaire.

For the second phase of the Delphi, this survey questionnaire was sent to the participants to rate the importance of characteristics and rank of these named by the group in the first phase. The questionnaire sent to participants on the 27th of November and 31 participants sent it back until the 24th of December, 2011.

In the third phase of the Delphi, after analyzing data gathered from the second phase, the researcher presented the results (mean and rankings) within the questionnaire in order to elicit consensus and divergence on items generated in the second round. The final questionnaire was sent to participants on the 5th of January, 2012 and 25 participants sent it back until the 17th of February, 2012. Because consensus in their responses was reached in the second round, the study was finalized after the third phase.

\section{Data Analysis}

Consistent with the methodology, the first round of the study was analyzed via qualitative way. Content analysis was conducted and the most frequently physical factors constituted the questionnaire items. For the quantitative part of the study, frequency analysis, mean and rankings, were conducted for each item by the researcher via SPSS.

\section{FINDINGS}

\section{Developing instrument: Results of the first phase}

In this part, instrument development process was explained as the results of the first round of the study. Data gathered from participants were firstly categorized into the firstly 14 themes; technology, ambient environment, furniture and materials, classroom, library, science laboratory, art spaces, canteen, garden, cleanliness and orderliness, recreation room, study room, size and other spaces. These themes constructed the first and the main part of questionnaire. 14 themes could be divided in two; important places and physical attributes that these places should have. Therefore, places and technology among these themes made of the dimensions. These places were classroom, library, science laboratory, art spaces, canteen, garden, recreation room, study room and corridor. Consequently, 10 main dimensions constituted a first part of the questionnaire. Under each dimension, items were related to the topics mentioned for each place itself in the first phase and the other four physical attributes including ambient environment, furniture and materials, cleanliness and orderliness and size. In this point, the objective was to establish a set of items that were relatively homogeneous for each dimension, therefore, for example, there was an item related to ambient environment under each dimension. This part of the questionnaire included 97 items followed by a five-point Likert scale ranging from "very important" to "not important". Additionally, teacher candidates were asked to rank each item under each dimension in order of importance. That is, if there were 10 items in one dimension, 1 showed the most important item while 10 indicated the least important item.

In the second part of questionnaire, participants were asked to prioritize 10 main dimensions in terms of professional, academic and individual development, therefore the order of importance 
of places were obtained according to for each development area. The third part was related to the other places which are mentioned by participants. These are conference hall, stationery and photocopy center, advisory center for their profession, office of each instructor, first-aid rooms for practice, student club rooms, large spacious corridors, meeting room used by both instructor and students, teaching materials laboratory, sports hall, theatre hall, exhibition room for teaching materials, room for watching educational films, practice school which is close to the faculty building, prayer room and adequate toilet. The participants were asked to rank the most important five places among these places. In the final part of the questionnaire, participants were asked to order the recourses in the library and also materials in bulletin board according to their importance.

\section{Results of the second and the third phase of the study}

In this part of the paper, mean and ranking of the most important physical characteristics were given in reference to Table 1. As shown in Table 1, mean scores are high ranging from 5 to 4.17. Among these dimensions, the mean of technology is higher than others. Also, items related to technology under other dimensions are among most important physical characteristics. It can be said that the difference between the first and the second questionnaire result is not high. This is the best exemplified with teacher candidates' ranking items under each dimension. Teacher candidates did not change their opinion about ranking related to library, science space, technology, canteen, recreation room, and corridor after the first questionnaire. When compared to the other rankings, the high differences were related to garden. For example, while the mean score of the item "attractive garden" increased from 4.58 to 4.78 , sequence of this item went up to 3 from 6 in parallel with the mean results. Again the sequence of the item "sport activity spaces" decreased from 3 to 7 with a mean of 4.38 and 4.17 , respectively.

Two items that were ranked last in dimensions were color and location. Color is the last ranking physical characteristic for seven places including classroom $(M=3,74$ and 3,39$)$, library $(M=3,80$ and 3,47$)$, art spaces $(M=3,64$ and 3,21$)$, science laboratory $(M=3,64$ and 3,22$)$, recreation room $(M=3,80$ and 3,34), study room $(M=3,93$ and 3,26), and corridor $(M=3,80$ and 3,43). As it can be seen above, the mean scores of the second questionnaire are lower than the first one. As well as color, location is another physical characteristic which has moved behind other items for art spaces, science laboratory, study room, canteen, and recreation room. It is essential to state that there is no dimension where these two physical characteristics are top ranked.

Table 1

Mean and order of the important physical characteristics

\begin{tabular}{lcccc}
\hline Places and Important Physical Characteristics & Rank1 & Rank2 & M1 & M2 \\
\hline Classroom & 1 & 1 & 4,83 & 4,86 \\
Adequate number of classroom & 2 & 2 & 4,83 & 4,95 \\
Technology enhanced classroom & 3 & 3 & 4,80 & 4,69 \\
Practice classroom & 4 & 6 & 4,74 & 4,39 \\
Classroom ambiance & 5 & 4 & 4,61 & 4,52 \\
Classroom size & 6 & 5 & 4,29 & 4,34 \\
Variety seating in the classroom & & & & \\
\hline
\end{tabular}


Table 1 (Continued)

\begin{tabular}{|c|c|c|c|c|}
\hline Places and Important Physical Characteristics & Rank1 & Rank2 & M1 & M2 \\
\hline \multicolumn{5}{|l|}{ Library } \\
\hline Adequate resource & 1 & 1 & 4,87 & 4,78 \\
\hline Individual study space & 2 & 2 & 4,83 & 4,86 \\
\hline Technology enhanced library & 3 & 3 & 4,87 & 4,78 \\
\hline Group study space & 4 & 4 & 4,51 & 4,78 \\
\hline Library in the faculty building & 5 & 5 & 4,70 & 4,65 \\
\hline \multicolumn{5}{|l|}{ Art Spaces } \\
\hline Art classroom & 1 & 1 & 4,41 & 4,39 \\
\hline Adequate material & 2 & 2 & 4,61 & 4,52 \\
\hline Creative Drama classroom & 3 & 4 & 4,38 & 4,45 \\
\hline Separate classroom for each art course & 4 & 5 & 4,22 & 4,21 \\
\hline Space for different activities & 5 & 3 & 4,61 & 4,52 \\
\hline \multicolumn{5}{|l|}{ Science Laboratory } \\
\hline Adequate equipment & 1 & 1 & 4,87 & 5 \\
\hline Appropriate conditions for experiment & 2 & 2 & 4,83 & 4,86 \\
\hline Laboratory for each discipline & 3 & 3 & 4,51 & 4,73 \\
\hline 24 hour open laboratory & 4 & 4 & 4,41 & 4,34 \\
\hline Laboratory ambiance & 5 & 5 & 4,51 & 4,21 \\
\hline \multicolumn{5}{|l|}{ Technology } \\
\hline Technology enhanced teaching spaces & 1 & 1 & 4,96 & 4,95 \\
\hline Technology enhanced building & 2 & 2 & 4,90 & 4,95 \\
\hline Computer laboratory & 3 & 3 & 4,90 & 4,95 \\
\hline \multicolumn{5}{|l|}{ Canteen } \\
\hline Canteen in the faculty building & 1 & 1 & 4,83 & 4,86 \\
\hline Clean canteen & 2 & 2 & 4,90 & 4,91 \\
\hline Large and spacious canteen & 3 & 3 & 4,60 & 4,60 \\
\hline \multicolumn{5}{|l|}{ Recreation Room } \\
\hline Comfortable furniture & 1 & 1 & 4,74 & 4,86 \\
\hline Silence room & 2 & 2 & 4,77 & 4,69 \\
\hline Variety resources such as newspaper & 3 & 3 & 4,64 & 4,39 \\
\hline \multicolumn{5}{|l|}{ Garden } \\
\hline Greenery garden & 1 & 1 & 4,64 & 4,86 \\
\hline Seating places & 2 & 2 & 4,83 & 4,82 \\
\hline Attractive garden & 6 & 3 & 4,58 & 4,78 \\
\hline Sport activity space & 3 & 7 & 4,38 & 4,17 \\
\hline \multicolumn{5}{|l|}{ Study Room } \\
\hline Individual study space & 1 & 1 & 4,90 & 5 \\
\hline Group study space & 2 & 2 & 4,64 & 4,95 \\
\hline Appropriate furniture & 4 & 3 & 4,83 & 4,95 \\
\hline Technology enhanced study room & 3 & 4 & 4,87 & 4,86 \\
\hline \multicolumn{5}{|l|}{ Corridor } \\
\hline Large and spacious corridor & 1 & 1 & 4,58 & 4,78 \\
\hline Regularly updated bulletin board & 2 & 2 & 4,61 & 4,78 \\
\hline
\end{tabular}


Additionally, teacher candidates were asked to rank the places according to their contribution to teacher candidates' professional, academic and individual development. According to the results, library is the first important place to enhance these developments. Classroom and technology enhanced building are other important places for professional and academic development especially. To develop individuality, art spaces have a significant role according to participants. Canteen and corridor are the last two sequenced places for all of the fields.

Related to resources in the library, teacher candidates prioritize current resources, periodical resources, course textbook used in teacher education, thesis and articles of their instructors, primary and secondary course textbooks and encyclopedia and dictionary, respectively. About bulletin boards, teacher candidates want to see the following materials, respectively; topical and useful information, important news (such as appointments), announcement about university activities, announcement and information about projects, announcement about competitions and panel, students' product, motivational materials like picture and photography, artistic picture and photographs. Teacher candidates stated the other important places for them. These are conference hall, photocopy center and stationery, meeting room, room for watching educational films, exhibition room for teaching materials, practice school which is close to the faculty building.

\section{DISCUSSION \& CONCLUSION}

The most important issue according to results is technology designed faculty building and the building in which every room is technologically equipped. As realized also by teacher candidates, developments in the computer and communication technologies open up new opportunities for learning design. There are lots of advantages of the Internet and technologies for education. They provide access and management of the information in productive and efficient ways. Therefore, graduates should be equipped with computer skills requirement in order to meet diverse skill demands of a technologically driven world (Quinton, 2006). Besides, while challenging all responsibilities, teachers should have mastery over multiple forms of information technology and know how to make effective use of technology in support of pedagogy and learning activities (Pellegrino \& Altman, 1995). Therefore, it can be concluded that because of these reasons and with the classrooms of tomorrow having been effectively designed with technology, faculties should design their learning environment and experiences for preservice teachers so that they can understand the realities of 21st century classrooms and schools (Pellegrino \& Altman, 1995).

About the classroom, classroom is still the main space according to teacher candidates differently than the literature. Milne (2006) identified a few trends after his 20 years of observation as a former director of Open University in Scotland and he concluded that (1) classrooms are not only form of learning space. As well as Milne, Oblinger (2006) defined the learning space patterns which are common in the 21st century: (1) space shaped by learning rather than by instruction, (2) socially catalytic space, (3) a shift from classrooms to learning complexes, (4) service philosophy, (5) technology integration, (6) experimentation and innovation, and (7) user involvement. The focus in two definitions, the new university environment is more than classroom to enhance social environment for not only for Education students but for all undergraduate students. In this study, participants' focus is the different function of the classroom. Dewey (1916) stressed the role of the classroom environment: "We 
never educate directly, but indirectly by means of the environment" (as cited in Kosnik \& Beck, 2009, p. 69). The classroom environment should be one that supports students learning (including personal growth generally), rather than undermining it. With respect to this aspect, teacher candidates' suggestion was to design a classroom physical environment which enables teaching practice. For example, having classroom designed like the real school classroom is so meaningful that it creates a genuine atmosphere.

Library is another place in the faculty building which has multiple functions for undergraduate and graduate students, academicians and researchers. Main functions of the library can be counted as: (1) reaching resources (books, dictionaries, e-resources, and etc.) and booking them; (2) individual study (on homework, project, article and so on); (3) group study (on lesson, project, and etc.); (4) reading novel, newspapers and so on. When these functions are considered, library support is fundamental to ensure the success of any college or university teacher education program (Uhl, 2007). In line with these functions of the library, results showed the same necessities of teacher candidates; adequate number of resources, spaces for individual and group study, respectively. According to them having these is more significant than having a library. Therefore, it can be worthwhile to provide teacher candidates with spaces (library, recreation room, study room and etc.) which include resources and spaces for group and individual study. The other issue about library is technology mentioned by teacher candidates. There is plentiful literature supporting this idea. For example, King (2000) stated the new roles of library in education in his study by giving two exemplary cases (La Trobe university library and universities in Australia). Flexibility, technology enhanced library and space for different activities are common and essential characteristics of the future library.

The corridor is counted as among the important places. As stated by Popenici and Brew (2013), restrictions imposed by the building design and general arrangement of transitional areas and corridors enhanced or limited in students' mind. Tor (2015), in her doctoral thesis, found that large and spacious corridors increase the interaction and communication among students, raise type of activity and enable students use the building out of class. As Alexander, Ishikawa, and Silverstein et al. (1977) proclaimed that if a building does not promote constant informal contact among its users, no social group survives. If students meet each other, they may share their experiences and a set of values. People with a shared way of life can form a community.

Interestingly color was the last important characteristics for each dimension according to teacher candidates unlike the literature review. This can be explained that the other physical characteristics are more vital than the color. In contrast; as stated by Walden (2009), there are many researches presenting that environments with color harmony can increase well-being and performance. Steiner stated that colors of spaces and objects do have real connections to a person's moods and feelings (as cited in Walden, 2009). It can be considered to develop further studies on color from teacher candidates' point of view via qualitative way. In the first part of the study, participants stated what they want but explanations and reasons behind these necessities were deficient so the other qualitative research methods like interview may be utilized to elaborate the issues.

As a conclusion, teaching profession is not just about transmitting knowledge. The responsibilities of teachers are uncountable and various. They are seen as artists, researchers, guides, facilitators, observers, clinicians, diagnosticians, and tacticians. Accordingly, the responsibility of a teacher candidate should not only be to study lesson and take a course, but 
they should also be active, and socialize with peers, and instructors. They ought to join in any club related to their interest to develop their personality and knowledge. They should be able to conduct research, to participate any academic activity like seminars, panels, to study individually and as a peer group. Moreover, they can observe real classroom environment to increase the awareness of teaching profession. To do all these, teacher candidates should be intrinsically forced. Teacher education program and their instructor are not enough to force them, it is also important to design faculty building in order to motivate them intrinsically. The following citation is a good example explaining this; "physical space provides a context for school practices, but also shapes and it's shaped by such practices" (Gordon \& Lahelma, 1996, p.303). Different learning scenarios occur whether we, administrator and/or faculty, arrange the spaces or not. According to Van Note Chism (2006), when spaces are designed in line with learning, deeper and richer learning is encouraged. So, environments should be designed to activate experience, stimulate the senses, encourage information exchange, and provide opportunities for rehearsal, feedback, application, and transfer in order to support learning (Van Note Chism, 2006).

\section{Implications for Further Research}

This study was conducted in order to identify teacher candidates' needs in terms of physical environment and to provide the most important places and physical attributes of an educational building. Each place prioritized by this research can be a focus of narrowed research in order to obtain more detailed information about its effect and role of students' diverse needs. Moreover, in this study, undergraduates from different departments consisted of participants of this study. For further research, the role and importance of the specific place (i.e classroom or library) and the physical attributes might be searched for specially one department.

\section{REFERENCES}

Alexander, C., Ishikawa, S., \& Silverstein, M. (1977). A pattern language. Newyork, NY: Oxford University Press.

Clayton, M. J. (1997). Delphi: a technique to harness expert opinion for critical decision-making tasks in education. Educational Psychology, 17(4), 373-386.

Edwards, R., \& Usher, R. (2000). Globalisation \& pedagogy: Space, place and identity. Canada: Routledge.

Gee, L. (2006). Human-centered design guidelines. In D. Oblinger (Ed.), Learning spaces. Washington: EDUCAUSE.

Gordon, T. \& Lahelma, E. (1996). School is like an Ant's Nest: Spatiality and embodiment in schools. Gender and Education, 8(3), 301-310.

Graetz, K. A., \& Goliber, M. J. (2002). Designing collaborative learning places: Psychological foundations and new Frontiers. In N.V.N. Chism \& J. Deborah (Eds.), The importance of physical space in creating supportive learning environments: New directions in teaching and learning (92, pp.13-22). Francisco: Jossey-Bass.

Jamieson, P. (2003). Designing more effective on-campus teaching and learning spaces: a role for academic developers. International Journal for Academic Development, 8(1-2), 119-133. 
Jessop, T., Gubby, L., \& Smith, A. (2011). Space frontiers for new pedagogies: a tale of constraints and possibilities. Studies in Higher Education, 37, 189-201. doi:10.1080/03075079.2010.503270

King, H. (2000). The Academic library in the 21st Century - what need for physical space? Iatul Proceedings, 10. Retrieved from http://educate.lib.chalmers.se/IATUL/proceedcontents/ qutpap/king_full.html

Kosnik, C., \& Beck, C. (2009). Priorities in teacher education: The 7 key elements of preservice preparation. Oxford: Routledge.

Linstone, H. A., \& Turoff, M. (Eds.). (2002). The Delphi method: Techniques and applications. Retrieved from http://www.is.njit.edu/pubs/delphibook/index.html

Oblinger, D. (2006). Space as a change agent. In , D. Oblinger (Ed.), Learning Spaces (pp.12-15). Washington, DC: EDUCAUSE. Retrieved from http://www.educause.edu/research-andpublications/books/learning-spaces

Miles, M. B., \& Huberman, M. A. (1994). Qualitative data analysis: An expanded sourcebook. Thousand Oaks. Sage.

Milne, A. (2006). Designing blended learning space to the student experience. In D. Oblinger (Ed.), Learning spaces. Washington: EDUCAUSE.

Moore, G. T. (1987). The physical environment and cognitive development in child-care center. In C. S. Weinstein, \& T. G. David (Eds), Spaces for children: the built environment and child development (pp. 41-72). New York, NY: Plenum Press.

Patton, M. Q. (2002). Qualitative research and evaluation methods. Thousand Oaks: Sage Publications.

Pellegrino, J. W., \& Altman, J. E. (1995). Information technology and teacher preparation: Some critical issues and illustrative solutions. Peabody Journal of Education, 72(1), 89-121.

Popenici, S. \& Brew, A. (2013). Reading walls on university corridors: transitional learning spaces in campus. In M. Vicars \& T. McKenna (Eds.), Discourse, power, and resistance (pp. 145- 156). Rotterdam: Sense Publishers.

Quinton, S. (2006). A brief critique on the future of learning: Assessing the potential for research. In M. Khine \& D. Fisher (Eds.), Contemporary approaches to research on learning environments: World views (p. 543- 578). Singapore: World Scientifc.

Sanoff, H., Pasalar, C., \& Hashas, M. (2001). School building assessment methods. Washington DC: National Clearinghouse for Educational Facilities.

Skulmoski, G. J., Hartman, F. T., \& Krahn, J. (2007). The Delphi method for graduate research. Journal of Information Technology Education, 6(1), 1-21.

Temple, P. (2007). Learning spaces for the 21st century: A review of the literature. Higher Education Academy, London. Retrieved from http://www.heacademy.ac.uk/assets/documents/research/Learning_spaces_v3.pdf

Temple, P. (2009). From space to place: University performance and its built environment. Higher Education Policy, 22, 209-223. doi:10.1057/hep.2008.30

Temple, P. (Ed.). (2014). The physical university: Contours of space and place in higher Education. London: Routledge. 
Erciyes Journal of Education 2017, Vol 1, No 2, 23-33

Tor, D. (2015). Exploring physical environment as hidden curriculum in higher education: A grounded theory study (Unpublished PhD thesis). Middle East Technical University, Ankara, Turkey.

Uhl, J. O. (2007). The curriculum materials center: Library support for a teacher education program. Collection Building, 26(2), 44-47.

Van Note Chism, N. (2006). Challenging traditional assumptions and rethinking learning spaces. In D. Oblinger (Ed.), Learning spaces (pp.16-27). Washington: EDUCAUSE.

Walden, R. (2009). The school of the Future: Conditions and Processes - Contributions of Architectural Psychology. In R. Walden (Ed.), Schools for the future: Design proposals from Architectural Psychology (p. 75-122). Cambridge: Hogrefe \& Huber Publishers.

Zeichner, K. (2008). Introduction: Setting for teacher education. In M. Cochran-Smith, S. Feiman-Nemser, \& D. J. Mclntyre (Eds.), Handbook of research on teacher education: Enduring questions in changing 13 contexts (p. 263-268). New York: Routledge, Taylor \& Frances and the Association of Teacher Educators. 